\title{
Pollination ecology of Clerodendrum inerme (L.) Gaertn. (Lamiaceae) in Coringa mangrove ecosystem, Andhra Pradesh, INDIA
}

\section{A.J. Solomon Raju ${ }^{1} \&$ Rajendra Kumar ${ }^{2}$}

${ }^{1}$ Department of Environmental Sciences, Andhra University, Visakhapatnam, Andhra Pradesh 530003, India ${ }^{2}$ Ministry of Environment, Forest and Climate Change, Indira Paryavaran Bhavan, Jor bagh Road, New Delhi 110003, India

${ }^{1}$ ajsraju@yahoo.com (corresponding author), ${ }^{2}$ kumar.rajendra@gov.in

ISSN 0974-7907 (Online) ISSN 0974-7893 (Print)

\section{OPEN ACCESS}

\begin{abstract}
Clerodendrum inerme (L.) Gaertn. (Lamiaceae) is bisexual, self-compatible and has a vector-dependent mixed breeding system. They are dichogamous and herkogamous; the day 1 flowers are staminate while the day 2 and 3 flowers are pistillate. The plant blooms in the evening, possesses a white long corolla with a hairy interior to exclude other insects and strong fragrance are adaptations for pollination by the hawk-moth Macroglossum gyrans. The $2^{\text {nd }}$ and $3^{\text {rd }}$ day flowers are nectar-rich and attract hawk-moths during the dawn and dusk hours. The plant is also visited by bees and butterflies. The bees Xylocopa and Anthophora are primary nectar robbers which collect nectar without effecting pollination. In C. inerme, three forms of flowers can be distinguished based on the position of sex organs. The first form is characterized by elongated stamens and a style which occur in close proximity to each other just after anthesis facilitating contact between the stamens and stigma. The second form is characterized by the scattered position of stamens and style. In the third form, the stamens are fully extended while the style is curved away from them, either to the left or to the right; subsequently the stamens curl inward and the style elongates. Interestingly, the three flower forms can be found within a cyme also. These forms of flowers with strong protandry prevent autonomous selfing but not geitonogamy. The fruit is a capsule and breaks open to disperse nutlets. Birds such as Acridotheres tristis, Corvus splendens, Corvus macrorhynchos and Turdoides caudatus disperse nutlets during the early winter season. Seeds germinate in June and seedlings grow gradually to produce new plants.
\end{abstract}

Keywords: Clerodendrum inerme, hawk-moth pollination, mixed breeding system, nectar robbery, protandry.

DOI: http://dx.doi.org/10.11609/jott.2276.8.5.8777-8787

Editor: V. Sampath Kumar, Botanical Survey of India, Howrah, India.

Date of publication: 26 May 2016 (online \& print)

Manuscript details: Ms \# 2276 | Received 05 September 2015 | Final received 15 April 2016 | Finally accepted 09 May 2016

Citation: Raju, A.J.S. \& R. Kumar (2016). Pollination ecology of Clerodendrum inerme (L.) Gaertn. (Lamiaceae) in Coringa mangrove ecosystem, Andhra Pradesh, India. Journal of Threatened Taxa 8(5): 8777-8787; http://dx.doi.org/10.11609/jott.2276.8.5.8777-8787

Copyright: @ Raju \& Kumar 2016. Creative Commons Attribution 4.0 International License. JoTT allows unrestricted use of this article in any medium, reproduction and distribution by providing adequate credit to the authors and the source of publication.

Funding: Self-funded.

Conflict of Interest: The authors declare no competing interests.

Author Details: PRof. A.J. SOLOMOn RAJu is the Chairman, Board of Studies in the Department of Environmental Sciences, Andhra University, Visakhapatnam. He is the recipient of several national and international awards. He is on the editorial board of several international journals. MR. RAJENDRA KUMAR is currently working as Research Officer in the Ministry of Environment, Forest and Climate Change, Government of India, New Delhi.

Author Contribution: Both the authors contributed to a similar extent overall.

Acknowledgements: We thank the Andhra University, Visakhapatnam for providing us facilities to carry out this work. 


\section{INTRODUCTION}

The genus Clerodendrum comprises about 500 species of small trees, shrubs, lianas, or occasionally perennial herbs. It is found in tropical and warm temperate regions of the world, with most of the species in tropical Africa and southern Asia, but with a few in the tropical Americas and northern Australasia, and a few extending north into the temperate zone in eastern Asia (Mabberley 2008). The members of the genus Clerodendrum are widely used in various indigenous systems of medicine for the treatment of diseases such as syphilis, typhoid, cancer, jaundice and hypertension. Different workers have studied a few species of Clerodendrum for their pollination aspects. Keng (1990) reported that C. laevifolium is pollinated by insects such as bees and butterflies and mentioned that birds feed on its fruits (berries) and in the process may act as fruit or seed dispersal agents for this species. $\mathrm{He}$ has also mentioned that this plant species is the larval host for the Fluffy Tit butterfly, Zelthus amasa maximinianus. Reddy \& Reddi (1995) reported that $C$. infortunatum exhibits geitonogamous and xenogamous modes of breeding. The Papilionoid butterflies (Papilio polytes, P. polymnestor and Atrophaneura hector) are the exclusive pollinators and effect pterigotribic pollination by striking the anthers and stigma with their wings. Meerabai (2014) also reported that in C. infortunatum, the flowers are adapted for pollination exclusively by butterflies due to non-promiscuity of floral rewards to other foragers. This pollination syndrome is a necessary pre-condition for the rise of the floral isolating mechanism. Shamim et al. (2010) reported that $C$. viscosum is exclusively cross-pollinated by ants, butterflies and hawk-moths. It does not set fruit through self-pollination and they experimentally proved by bagging the flowers. Rohitash \& Jain (2010) noted that C. splendens is pollinated by Xylocopa, Eumenes sp. and Camponotous campestris. The plant produces fruit and seed set through geitonogamy and xenogamy only. McMullen (2011) reported that $C$. molle produces fruit via open-pollination, autonomous autogamy, facilitated autogamy, facilitated cross-pollination, diurnal pollination and nocturnal pollination. He also noted that cross-pollinated flowers showed a significant increase in seed set and is pollinated by nocturnal and diurnal visitors. Nocturnal visitors include ants, spiders, hawk-moth $s$, and roaches whereas diurnal visitors include carpenter bees and ants. Mcmullen also stated that other studied species of Clerodendrum are fully protandrous and incapable of autonomous autogamy.
Sakamoto et al. (2012) reported that $C$. trichotomum is protandrous and shows two distinct sexual phases. The staminate phase begins when the flower opens, and this is followed by the pistillate phase. It is effectively pollinated by Papilio and Xylocopa species while the hawk-moth, Macroglossum is not an effective pollinator but may contribute to self-pollination. Primack et al. (1981) reported that $C$. inerme is strongly protandrous and visited by the hawk-moth during the dusk hours; there were no daytime visitors. With this backdrop, the present study was contemplated to provide the details of pollination ecology of $C$. inerme, a prominent landward shrub in the Coringa Mangrove Ecosystem in Andhra Pradesh, India. This information is useful to understand the importance of local insects in pollination ecology and birds in seed dispersal and subsequent recruitment within the mangrove cover.

\section{MATERIALS AND METHODS}

The Godavari mangrove wetland lies between $16^{\circ} 30^{\prime}-17^{\circ} 00^{\prime} \mathrm{N}$ and $82^{\circ} 10^{\prime}-80^{\circ} 23^{\prime} \mathrm{E}$ in the State of Andhra Pradesh, India. In this wetland, $C$. inerme grows along the creeks and towards land; it is distributed sparsely in this mangrove forest. The plant is characteristically deciduous during the dry season, displays seed germination, leaf flushing, flowering, fruiting and seed dispersal during the wet season. Field studies and lab-work were made during the period from February 2011 to June 2014.

The protocols mentioned in Raju \& Rajesh (2014) were followed to examine the flowering season, floral morphological characters, sexual system, anthesis schedule, anther dehiscence timing, pollen output, pollen-ovule ratio, nectar aspects such as volume, sugar concentration, sugar types, sugar content, amino acids, stigma receptivity, breeding systems, fruiting aspects such as natural fruit set rate, fruit maturation period, dehiscence and seed dispersal, insect foragers, their foraging behavior and pollen carrying efficiency.

\section{RESULTS}

A shrub, grows up to $2 \mathrm{~m}$ (Image 1). It sheds leaves continually but leaf shedding is prominent during the dry season and exhibits profuse leaf flushing during the rainy season. The flowering occurs from August to October, profusely during September (Image 2a). The inflorescence is characteristically a 3-flowered cyme 


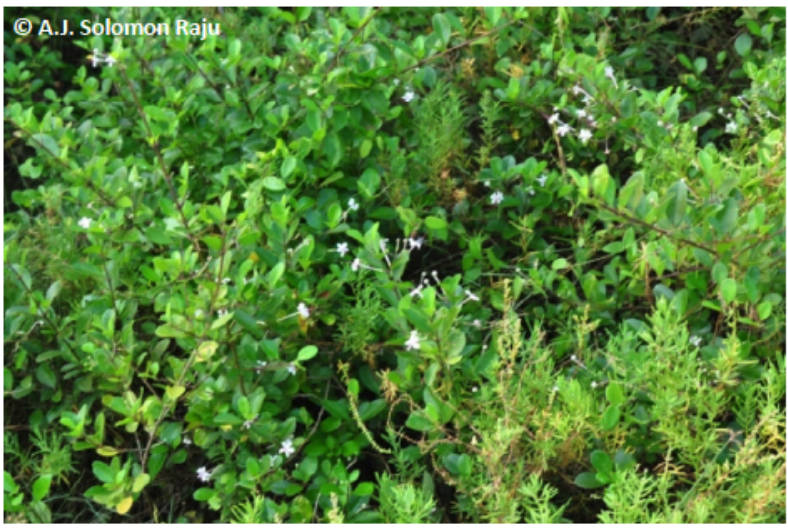

Image 1. Clerodendrum inerme - Habit.

borne in axillary position and all the three flowers have a common base point (Image 2b). Individual cymes produce all three flowers either on the same day or within 2-3 days (Image 2c-d). The production of flowers within cymes is dependent on the developmental stage of individual flowers. Usually, the central flower emerges first followed by the lateral flowers. The flowers orient completely or partly erect.

\section{Flower morphology}

The flowers are pedicellate, large $(35-40 \mathrm{~mm})$, fragrant, zygomorphic and bisexual. Calyx is green, gamosepalous consisting of five sepals, cup-shaped, $8 \mathrm{~mm}$ long, 3-4 $\mathrm{mm}$ wide and valvate at the tip. Corolla is white, tubular (30mm long), 4-5 lobed at the tip; each lobe $10-12 \mathrm{~mm}$ long and $4-5 \mathrm{~mm}$ wide, and reflexed. The ratio of 4 and 5 corolla lobes is $1: 21$. On the inner surface, the corolla tube is covered with short fine hairs up to the point of attachment of staminal filaments. The stamens are 4 or 5 , epipetalous, exserted, extend up to $30 \mathrm{~mm}$ from the corolla mouth when the flowers first open. The included part of the filaments is white, while the exserted part of the filaments is purple. The ratio of flowers with four stamens and five stamens is
12: 1 . There is a great variation in the length of stamens despite their common point of origin on the corolla tube. In case of flowers with four stamens, two long and two short or all stamens are equal in length while in the case of flowers with five stamens, two are long and three are short. The anthers have versatile fixation, dark-coloured, dithecous and introrse. The ovary has two carpels but it is tetra-locular due to the formation of a false septum (Image $4 \mathrm{e}, \mathrm{f}$ ). The ovules vary in number from 2-4 but 4-ovuled flowers are common (Image $4 \mathrm{~g}$ ) and are erect, anatropous and arranged on axile placentation. The total length of style is $45 \mathrm{~mm}$ in $1^{\text {st }}$ day flowers and $56 \mathrm{~mm}$ in the $2^{\text {nd }}$ and $3^{\text {rd }}$ day flowers. The included part of the style length is $30-33 \mathrm{~mm}$ while the exserted part of the style length is $15-18 \mathrm{~mm}$. In the case of the $2^{\text {nd }}$ and $3^{\text {rd }}$ day flowers, the exserted part of the style length is $25-28 \mathrm{~mm}$. The style with simple bifid stigma and lobes unequal (Image 4d).

\section{Floral biology}

The mature buds with coiled stamens inside open from 15:00-18:00 hr by the splitting of petal lobes (Image 4a). Petals expand and reflex immediately; then the stamens, style and stigma extend beyond the rim of the corolla tube (Image 4b). The pattern of stamens and style positions is different and is distinguished into three forms. In the first form of flowers, the stamens and style are elongated and in proximity to each other soon after anthesis which facilitates contact with each other (Image 3a). In the second form of flowers, the stamens and style are splayed (Image $3 b$ ). In the third form of flowers, the stamens are fully extended, but the style is curved away from them; the style in some flowers moves away to the left side (Image 3c) while in some others, to the right side (Image 3d). Later, the stamens curl inward and style is left elongated. All these three forms occur even within the cyme and occur almost in equal numbers at plant level. The anthers dehisce one hour after anthesis by longitudinal slits exposing the golden yellow pollen.
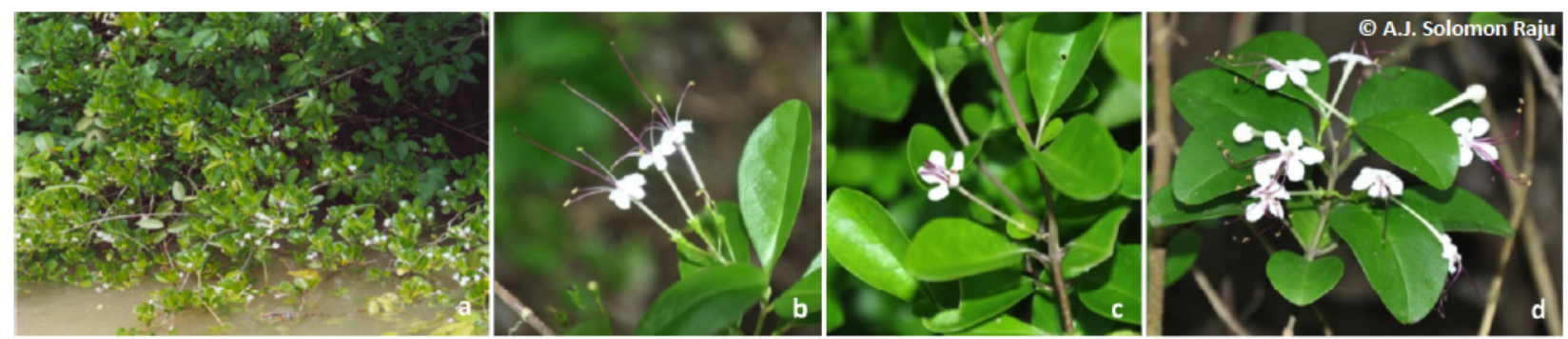

Image 2. Clerodendrum inerme: a - Flowering phase; b - Simultaneous anthesis of all the three flowers of the cyme; c - Two flowers already dropped from the cyme; $d$ - Flowering cymes. 

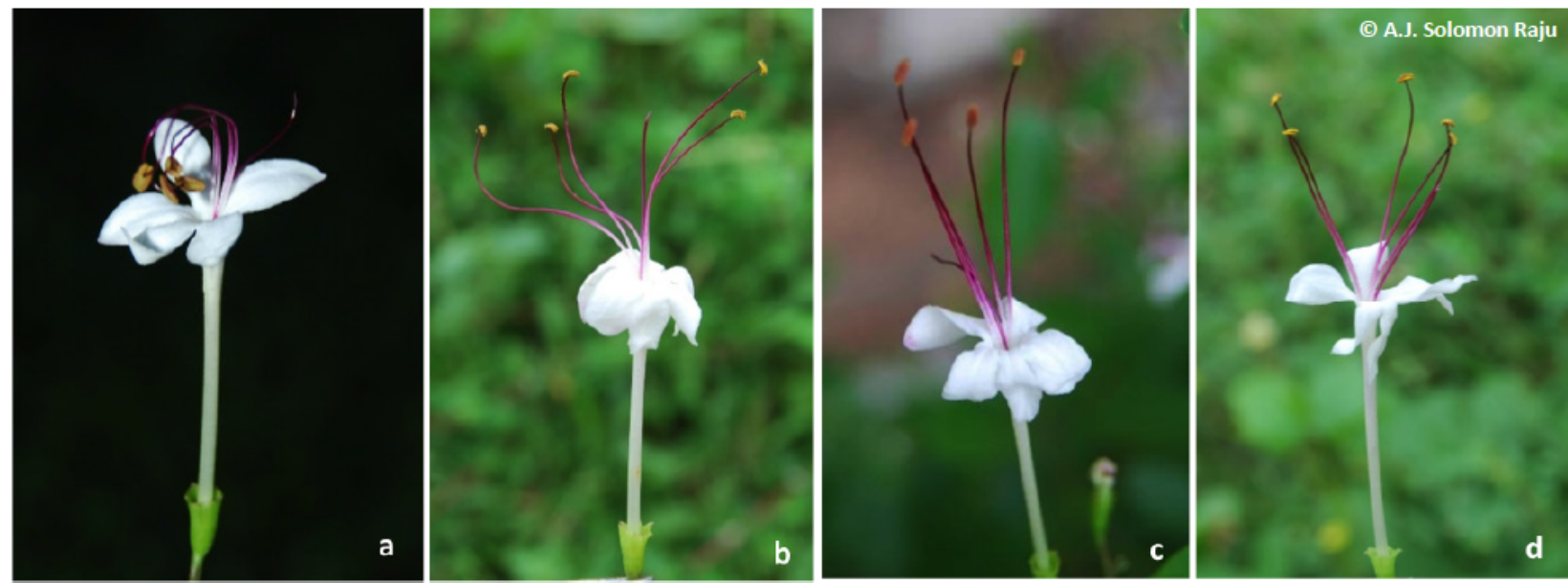

Image 3. Clerodendrum inerme: a - Stamens and style in close proximity to each other; b - Stamens and style are splayed; c - Stamens are fully extended and the style is oriented to the left; $d$ - Stamens are fully extended and the style is oriented to the right.

All the stamens ( 4 or 5 ) are fertile and produce almost the same number of pollen grains. The pollen output per anther is $796 \pm 51.2$. The total pollen productivity in flowers with 4 stamens is 3,184 and in 5-stamens is 3,980 . The pollen grains are tricolporate, prolate, ectocolpus long narrow with acute ends, reticulaterugulate with spinules widely distributed and $66.4 \pm 1.32$ $\mu \mathrm{m}$ long and $52.2 \pm 0.8 \mu \mathrm{m}$ wide (Image $4 \mathrm{c}$ ). The stigma with forked lobes is not receptive at and after anthesis but it is receptive with divergent lobes on the $2^{\text {nd }}$ and $3^{\text {rd }}$ day. Nectar is secreted during post-anthesis period. Its secretion is gradual from anthesis onwards but its volume is measurable on the $2^{\text {nd }}$ and $3^{\text {rd }}$ day. A flower produces $3.5 \pm 1.2 \mu \mathrm{l}$ of nectar which is secreted around the ovary and well protected due to the tubular nature of the corolla. The nectar sugar concentration is 13-21 $\%$ and the common sugars include sucrose, glucose and fructose. The total sugar content in the nectar of a flower is $0.37 \pm 0.06 \mathrm{mg}$ (range $0.24-0.46$ ). The nectar amino acids include the essential amino acids such as isoleucine, valine, lysine, methionine and threonine, and non-essential amino acids such as alanine, butyric acid, glutamic acid, hydroxyl-proline, serine and aspartic acid. The corolla together with stamens and stigma falls off after three days. The calyx is persistent, gradually bulges and encloses the fruit in case of fertilized flowers. The entire flower together with pedicel falls off if it is not pollinated or fertilized.

\section{Breeding systems}

The results of breeding systems indicate that the flowers are self-compatible and self-pollinating. The fruit set is absent in autonomous and facilitated autogamy, $30 \%$ in geitonogamy, $83 \%$ in xenogamy and
Table 1. Results of breeding experiments on Clerodendrum inerme

\begin{tabular}{|l|c|c|c|}
\hline Mode of pollination & $\begin{array}{c}\text { No. of flowers } \\
\text { pollinated }\end{array}$ & $\begin{array}{c}\text { No. of flowers } \\
\text { set fruit }\end{array}$ & $\begin{array}{c}\text { Fruit set } \\
\text { (\%) }\end{array}$ \\
\hline $\begin{array}{l}\text { Autonomous } \\
\text { autogamy (bagged) }\end{array}$ & 30 & 0 & 0 \\
\hline $\begin{array}{l}\text { Facilitated autogamy } \\
\text { (hand-pollinated and } \\
\text { bagged) }\end{array}$ & 25 & 0 & 0 \\
\hline Geitonogamy & 30 & 9 & 30 \\
\hline Xenogamy & 30 & 25 & 83 \\
\hline Open-pollination & 70 & 27 & 38 \\
\hline
\end{tabular}

$38 \%$ in open pollinations (Table 1).

\section{Foraging activity and pollination}

The flowers are specialized and the stamens and stigma are exposed when the petals unfold and reflex. The hawk-moth Macroglossum gyrans was the first visitor to the flowers. It began its nectar-foraging activity as soon as the flowers open during the late evening and dusk hours. Again, this moth foraged during the dawn hours from 05:00-07:00 h (Fig. 1). It did not forage at other times of the day. The bees (Xylocopa pubescens and Anthophora bicincta) and butterflies (Pareronia valeria, Danaus genutia and Barbo cinnara) foraged during the day time from 08:00 to 17:00 h (Fig. 1), but the bees showed more activity from 08:00-12:00 $\mathrm{h}$ while butterflies from 08:00-11:00 h (Table 2, Fig. 2). However, the overall foraging activity of these daytime foragers was not very intense and also their foraging visits were not very frequent. Of the total foraging visits, the hawk-moth made $39 \%$, butterflies $38 \%$ and bees $23 \%$ of visits (Fig. 3). The body washings of 

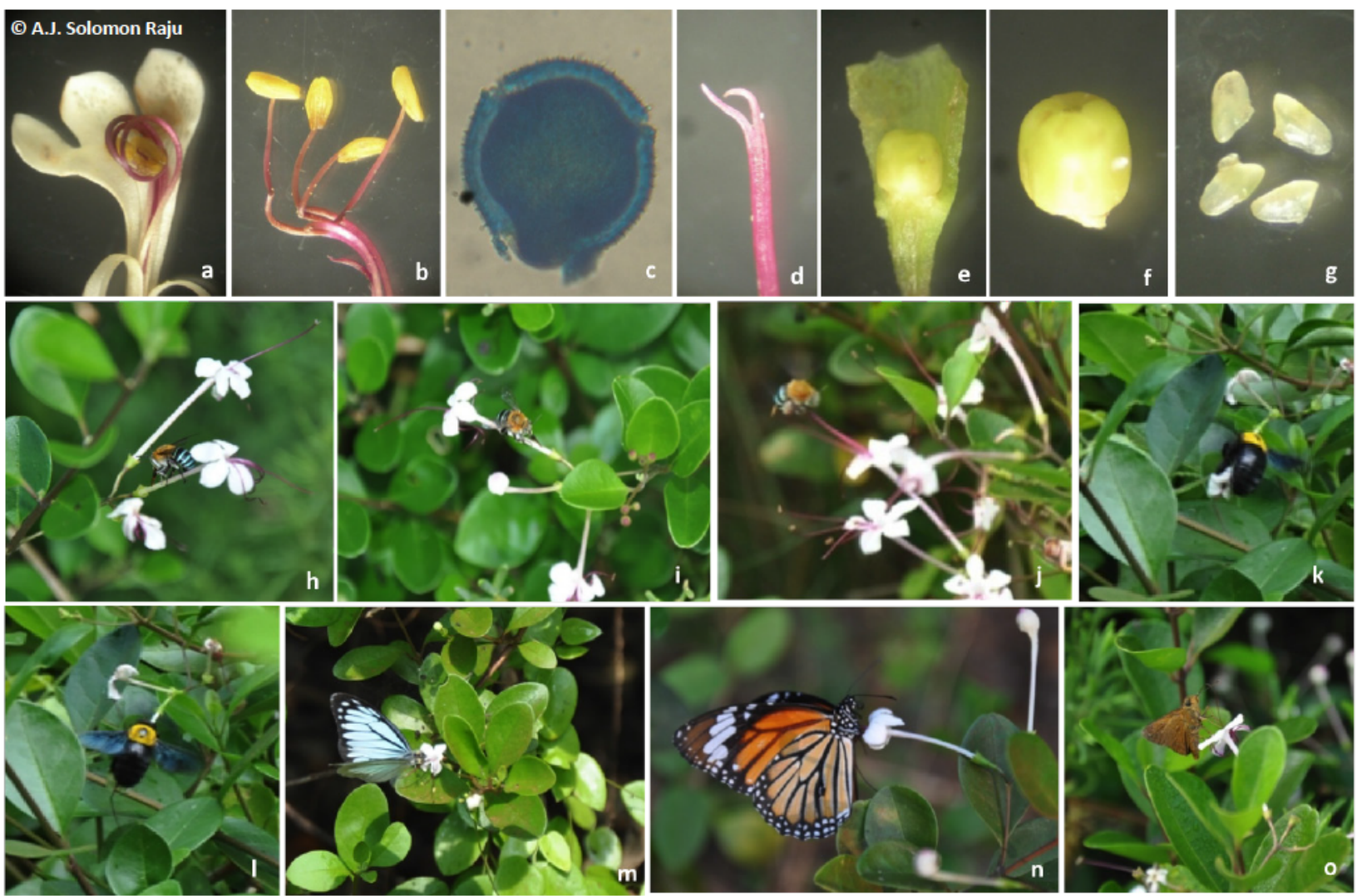

Image 4. Clerodendrum inerme: a - Coiled stamens in bud stage; b - Uncoiling of stamens; c - Pollen grain; d - Bifid stigma; e \& $\mathrm{f}$ - Ovary; g- Ovules; h \& i - Anthophora bicincta collecting nectar by puncturing the corolla tube; j - Anthophora bicincta collecting pollen;

k \& I - Xylocopa pubescens collecting nectar by puncturing corolla tube; $\mathbf{m}$ - Pareronia valeria attempting to collect nectar; $\mathbf{n}$ - Danaus genutia collecting nectar; o - Barbo cinnara collecting nectar.

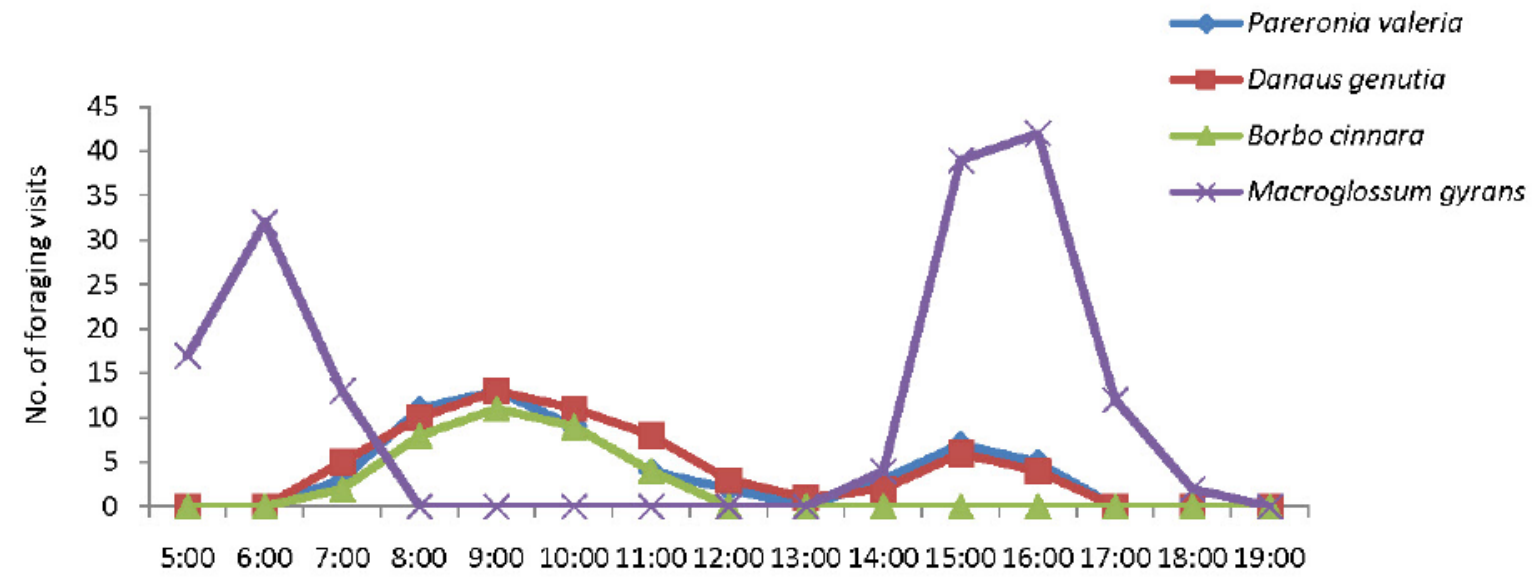

Time (h)

Figure 1. Hourly foraging activity of butterflies and hawkmoth on Clerodendrum inerme

these foragers collected from the flowers revealed the presence of pollen in different numbers depending on the frequency of foraging visits, extent and certainty of contact between the stamens and stigma and the wings and the abdomen of the foragers (Table 3). The hawk- moth is an efficient carrier of pollen and also consistent foragers with great intensity at the flowers during the entire period of flowering. The daytime foragers were not efficient carriers of pollen, not very frequent foragers and also not consistent ones during the entire 
Table 2. List of insect foragers on Clerodendrum inerme

\begin{tabular}{|c|c|c|c|c|c|}
\hline Order & Family & Genus & Species & Common name & Forage sought \\
\hline \multirow[t]{2}{*}{ Hymenoptera } & Apidae & Xylocopa & pubescens L. & Large Carpenter Bee & Pollen + Nectar \\
\hline & Anthophoridae & Anthophora & bicincta $\mathrm{F}$. & Blue Banded Bee & Pollen + Nectar \\
\hline \multirow[t]{4}{*}{ Lepidoptera } & Pieridae & Pareronia & valeria $\mathrm{Cr}$. & Common Wanderer & Nectar \\
\hline & Nymphalidae & Danaus & genutia $\mathrm{Cr}$. & Striped Tiger & Nectar \\
\hline & Hesperiidae & Borbo & cinnara Wallace. & Rice Swift & Nectar \\
\hline & Sphingidae & Macroglossum & gyrans Walker & Diurnal hawk-moth & Nectar \\
\hline
\end{tabular}

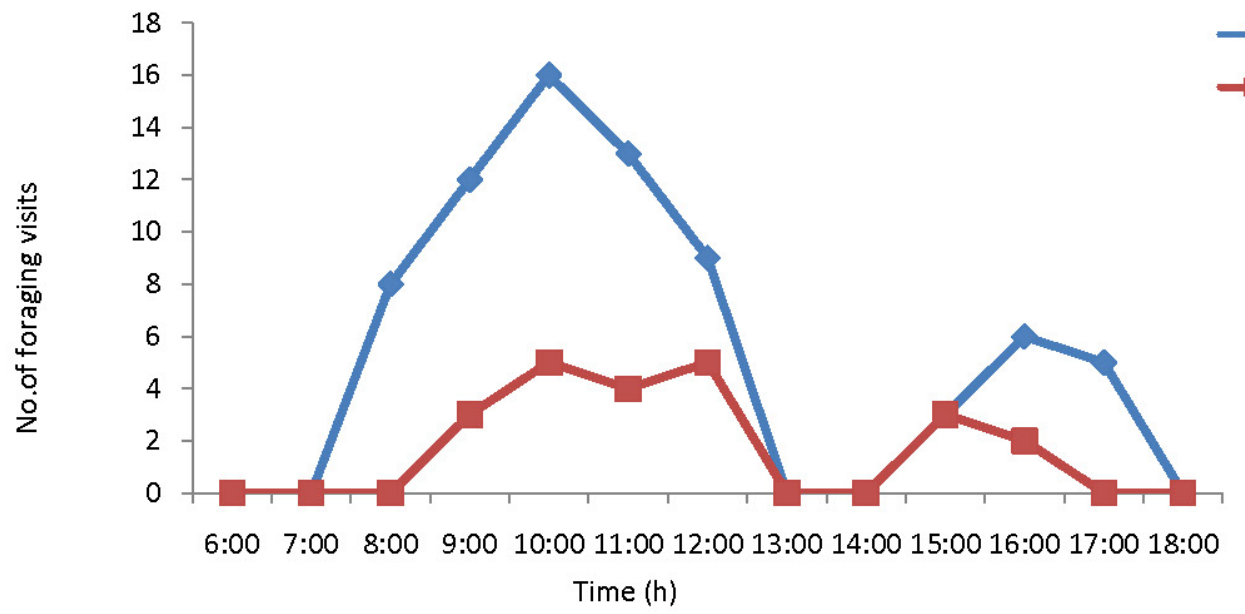

Figure 2. Hourly foraging activity of bees on Clerodendrum inerme

period of flowering.

The hawk-moth is a very swift flier and spins around the flowers in quick succession collecting nectar from a number of flowers on the same plant. It also makes inter-plant movements frequently for nectar collection from the fresh as well as $2^{\text {nd }}$ and $3^{\text {rd }}$ day flowers. This moth with a $32.5 \mathrm{~mm}$ long proboscis, is very successful in reaching the nectar location at the corolla base. While approaching the flower and collecting nectar from the flowers, it contacts the stamens and stigma of the same or different flowers with its wings and abdomen always and this foraging behavior ends up in pollination. The just open flowers available during the dusk hours with little nectar volume driving the moth to make multiple visits to these flowers as well as $2^{\text {nd }}$ and $3^{\text {rd }}$ day flowers in which nectar is richly available, on the same and different plants. Such a foraging behavior is considered to increase opportunities for cross-pollination.

Among the bees, Xylocopa pubescens is an exclusive nectar forager and Anthophora bicincta is both a pollen and nectar forager. These two bee species robs the nectar by making holes through the corolla tube by bypassing the floral sex organs. Xylocopa pubescens makes a hole at the mid-part of the corolla tube to collect nectar (Image $4 \mathrm{k}, \mathrm{I}$ ); the exact point where the hole is being made is mostly at the origin point of the epipetalous stamens covered with short hairs. The flower hanged downwards when this bee species with its heavy body weight landed on the corolla tube. Then, the nectar freely flowed through the grooves present on the inside of the corolla tube from the flower base to this fixed position of stamens. The short hairs present at the fixed point of stamens prevent the flow of nectar beyond this point towards the mouth of the corolla tube. On the contrary, A. bicincta makes a hole through the corolla tube at the flower base and robs nectar bypassing the floral sex organs (Image $4 \mathrm{~h}, \mathrm{i}$ ). The flower did not hang downwards when this bee species with light body weight landed and this might be the reason for the bee to move to the corolla base to rob the nectar. The nectar-robbing by these two bee species do not contribute to effecting pollination. However, these 
Table 3. Pollen recorded in the body washings of insects on Clerodendrum inerme

\begin{tabular}{|l|c|c|c|c|}
\hline Insect species & $\begin{array}{c}\text { Sample size } \\
\text { (N) }\end{array}$ & \multicolumn{3}{|c|}{$\begin{array}{c}\text { Number of pollen grains } \\
\text { Range Mean S.D }\end{array}$} \\
\hline Xylocopa pubescens & 10 & $13-48$ & 30.3 & 10.70 \\
\hline Anthophora bicincta & 10 & $54-126$ & 85.3 & 22.87 \\
\hline Pareronia valeria & 10 & $21-56$ & 38.1 & 11.63 \\
\hline Danaus genutia & 10 & $14-73$ & 35.9 & 16.12 \\
\hline Barbo cinnara & 10 & $11-21$ & 13.6 & 2.4 \\
\hline Macroglossum gyrans & 10 & $131-214$ & 179.1 & 32.5 \\
\hline
\end{tabular}

bees with vibrating wings in flight mode contacted the stamens and stigma occasionally while approaching the flowers. Such individual bees captured pollen on their wings and underside of the abdomen and these could effect pollination. Further, $A$. bicincta also collects pollen from individual anthers (Image 4j).

Among butterflies, the foraging visits of Pareronia valeria (Image $4 \mathrm{~m}$ ) and Danaus genutia (Image $4 \mathrm{n}$ ) are relatively frequent when compared to those of Barbo cinnara (Image 4o). In P. valeria, the body length is $25.6 \mathrm{~mm}$ and the proboscis length is $29.5 \mathrm{~mm}$, while in $D$. genutia and $B$. cinnara the body length is $23.9 \mathrm{~mm}$ and $14.1 \mathrm{~mm}$ with proboscis length of $12.2 \mathrm{~mm}$ and $17.5 \mathrm{~mm}$ respectively. In $P$. valeria and $D$. genutia, their body length facilitates them to have contact between the stamens and stigma in flight mode and while approaching the flowers and such an approaching behavior could make the butterflies capture pollen onto their wings as well as the underside of the abdomen and eventually effect pollination. Such contacts were found to be related to the path and position the butterflies take to access the flowers. In B. cinnara, the body length is short and its contact with the stamens and stigma is rare while approaching the flowers. All the three butterfly species probed the flowers by inserting their proboscis into the throat of the corolla tube. But, the corolla tube length was far in excess of the length of the proboscis of these butterflies, thus flowers in erect or partially erect position deprived the foraging butterflies of nectar. The butterflies however are successful in gaining access to nectar in the hanging flowers in which the nectar reaches the mid-part of the corolla tube; such flowers acquired this orientation due to visits to them previously by the bee, Xylocopa pubescens.

\section{Fruiting}

Pollinated and fertilized flowers initiate fruit development immediately and take 20-25 days to

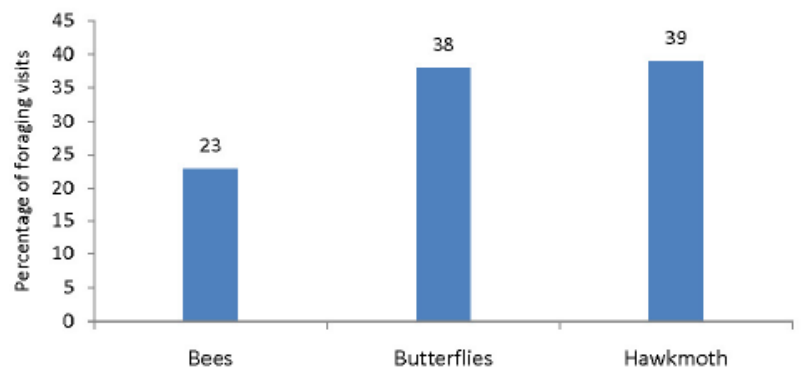

Figure 3. Foraging visits of different categories of insects on Clerodendrum inerme
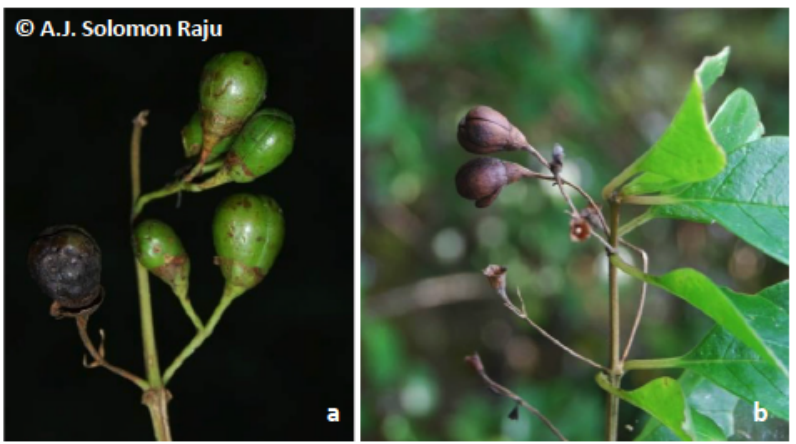

Image 5. Clerodendrum inerme: a - Green maturing fruits; b - Mature and dry fruits about to shed seeds.

produce mature fruits. The fruit is a capsule, ovalshaped, 10-15 mm long, green initially (Image 5a) and black when ripe and dry (Image 5b). Dry fruits split or break into 2-4 lobes depending on the number of ovules fertilized, each with a thick corky wall and a nutlet. Fruit dispersal occurs from November-December. Birds such as Acridotheres tristis (Indian Myna), Corvus splendens (House Crow), Corvus macrorhynchos (Jungle Crow) and Turdoides caudatus (Common Babbler) feed on the nutlets and in the process disperse them to different places. Nutlets germinate during the rainy season soon after the first monsoon rains in June.

\section{DISCUSSION}

Mangrove species are usually categorized as "exclusive" species that are limited to the mangrove environment and "non-exclusive" species that are mainly distributed in a terrestrial or aquatic habitat but also occur in the mangrove ecosystem. These nonexclusive species are referred to as semi-mangroves, back mangroves or mangrove associates (Tomlinson 1986; Parani et al. 1998; Lacerda et al. 2002). In the 
case of Clerodendrum inerme, there is a controversy with reference to its status as a constituent of mangrove forests. Parani et al. (1998) reported that it is a fringe species found abundantly both on the landward edge as well as deep inside the mangrove environment. Saenger (2002) considered it as a mangrove, but Satyanarayana et al. (2002) did not consider it as a mangrove species. Wang et al. (2011) reported that $C$. inerme behaves like both a true mangrove and a mangrove associate due to its largest salinity tolerance. Nevertheless, in this study, $C$. inerme is considered as a mangrove associate. It is a shrub that occurs predominantly in the mangrove forests and along the coastlines. It is exposed to a wide range of fluctuations in salinity due to its occurrence in the landward sites as well as in the open sites within the mangrove zonations at the study area. Therefore, it plays an important role in the formation and stabilization of the forest floor due to its prolific growth.

$C$. inerme blooms during the rainy season and produces typical 3-flowered cymes which are quite prominent and displayed well because of its white flowers against the bright green foliage. Primack et al. (1981) reported that this species produces 2-8 flowers in each cyme and this report does not agree with the present study indicating that each cyme is 3-flowered. Further, these authors noted that the flowers in a cyme generally remain at the same developmental stage, so that the flowers in the same cyme are unlikely to pollinate each other. In the present study, it is found that the flowers within the cyme show different developmental stages, open whether on the same day or over a period of three days at the most. This difference in developmental stages of flower buds is most likely to pollinate each other if pollinators are available. Further, the cymes of different branches of the same plant also show various developmental stages so that the cymes of the same plant pollinate each other through geitonogamy if there is pollinator activity.

The flowers open during the morning hours in Clerodendrum infortunatum (Reddy \& Reddi 1995) and during the late evening hours in $C$. molle in which the flowers are fragrant (McMullen 2011). In C. inerme, the flowers are fragrant and open during the evening hours as in C. molle. Primack et al. (1981) also reported that the flowers are fragrant but they have not mentioned the time of flower-opening. These authors stated that the calyx cup is covered with an irregular series of raised elliptical glands which apparently function as extrafloral nectaries and ants commonly feed on them. In the present study, $C$. inerme does not show such glands on the calyx cup and also the ants do not visit the flowers.
Yao-Wu et al. (2010) stated that an unusual pollination syndrome that prevents self-pollination exists in the genus Clerodendrum. This pollination syndrome is functional through dichogamy and herkogamy. The usual floral mechanism is that when the flower opens, the stamens stand erect, parallel to the central axis of the flower, while the style bends over, holding the stigma beyond the rim of the corolla. After the pollen is shed, the stamens curl up or bend over, and the style straightens out, bringing the stigma to the center of the flower. Such a movement and function of floral sex organs precludes self-pollination. Keng (1990) reported that $C$. laevifolium is pollinated by insects such as bees and butterflies. Reddy \& Reddi (1995) reported that C. infortunatum with morning anthesis is exclusively pollinated by papilionoid butterflies; the pollination occurs due to the striking of anthers and stigma with the wings of butterflies. Such a form of pollination is referred to as pterigotribic pollination. Meerabai (2014) reported that the typical butterfly pollination in $C$. infortunatum is because of non-promiscuity of floral rewards to other foragers. She also noted that this pollination syndrome is a necessary pre-condition for the rise of floral isolating mechanism. Shamim et al. (2010) reported that $C$. viscosum is exclusively cross-pollinated by ants, butterflies and hawk-moths. Rohitash \& Jain (2010) noted that $C$. splendens is pollinated by Xylocopa sp., Eumenes sp. and Camponotous campestris. McMullen (2011) reported that $C$. molle with night late evening anthesis is pollinated by nocturnal and diurnal visitors. Nocturnal visitors include ants, spiders, hawk-moth s, and roaches whereas diurnal visitors include carpenter bees and ants. Sakamoto et al. (2012) reported that C. trichotomum is pollinated by the carpenter bees, Xylocopa species, the butterflies, Papilio species and the hawk-moth Macroglossum sp. Primack et al. (1981) reported that $C$. inerme is never visited by daytime visitors but is visited by one large hawk-moth during the dusk hours.

C. inerme with evening anthesis, white long corolla with hairy interior to exclude other insects and strong fragrance appear to be adaptations for hawk-moth pollination (Primack et al. 1981). In the present study, it is visited and pollinated by one large hawk-moth, Macroglossum gyrans as soon the flowers are open during the evening hours. It is a nectar feeder but the nectar in just open flowers is almost absent. The new flowers take one to two hours to secrete nectar that compels the hawk-moth to pay multiple visits to the new as well as old flowers. The flowers opened one or two days before are nectar-rich and serve as the principal 
nectar source for the visiting hawk-moths during the evening hours. Further, the same hawk-moth is the first visitor to the flowers on the following day during the dawn hours by which time the flowers accumulate nectar in considerable amounts. The nectar is in considerable volume, sucrose-rich with a sugar concentration of 13$21 \%$, agrees with the report of Cruden et al. (1983). Further, it is a source of certain essential and nonessential amino acids, and protein content. In the present study, the hawk-moth being a swift flier visits numerous flowers on the same and different plants in quick succession in order to quench its thirst for nectar and in effect contributes to both self (geitonogamy) and cross-pollination. Primack et al. (1981) presumed that the purple color of the filament and style presumably make them difficult for the hawk-moth to see and avoid. The versatile anthers with pollen in grooves, allow pollen to be placed precisely on the hawk-moth proboscis. In the present study, Macroglossum gyrans approaches the flowers either laterally or from the front through the stamens and stigma to insert its proboscis into the corolla tube to collect nectar. In this process, its contact with the stamens and stigma are random but not with certainty and also there is no precise placement of pollen from the versatile anthers on the proboscis of the moth. The pollen deposition largely occurs on the wings and abdomen. Further, the production of a small quantity of pollen in individual flowers of $C$. inerme is another indication that it is adapted for nectar-feeding lepidopteran, in this case $M$. gyrans. Therefore, $M$. gyrans is to be considered as the principal pollinator of C. inerme.

C. inerme is, however, also visited by day-time visitors such as butterflies and bees but their overall foraging activity is low and also is not consistent throughout the flowering period. The butterflies with their short proboscis are not capable of collecting nectar from the long tubular corolla but they are successful in collecting nectar from the flowers that were previously visited by Xylocopa bees. Such flowers stay in a hanging position and the nectar is accumulated at the attachment point of staminal filaments covered by internal hairs. The butterflies access this nectar with their proboscis without any difficulty. The Xylocopa bee makes a hole on the mid-part of the corolla tube where the epipetalous stamens take their origin, which are covered by short hairs inside. When Xylocopa lands on the corolla tube, the flower hangs downward and as a result, the nectar flows to the attached point of stamens; then the bee collects nectar by making a hole on the corolla tube. The Anthophora bee also makes a hole to collect nectar but it does so at the base of the corolla tube. This is because its light weight does not bring the flower to a hanging position when it lands. Therefore, the two bee species are typical nectar robbers. Both the butterflies and bees however contribute to sporadic pollination while approaching the flowers during which their wings and abdomen strike the anthers and style.

Nectar robbing is a behavior exhibited by some species of bees in which nectar is obtained through holes made by puncturing near the bases of the corolla tubes. Nectar robbers are subdivided into primary nectar robbers which make the holes and then extract the nectar and secondary nectar robbers which obtain nectar by using holes made by primary robbers (Inouye 1983). Carpenter bees are the most notorious primary nectar robbers (Barrows 1980), make perforations with their maxillae (Barrows 1976) and this method is probably used by all Xylocopa bees (van der Pijl 1954). These bees employ this method when they are unable to access nectar and exists mostly in tubular flowers (Barrows 1980). In the present study, species of Xylocopa and Anthophora are considered as primary nectar robbers since they make holes on the corolla tube of $C$. inerme and secondary robbers of nectar are absent.

Nectar robbing is variously interpreted in relation to host fitness. It has positive or neutral or mutualistic effects on host fitness in terms of increase or decrease or no effect in seed set rate (Zhang et al. 2009). The removal of floral nectar by robbers decreases the standing crop and in some cases changes the sugar concentration of nectar available to other pollinators (Pleasants 1983). Longer pollinator flight distances generally translate into increased pollen flow and increased outcrossing rates (Fenster 1991). If nectar robbers are the cause of longer flight distances by the legitimate pollinators, they could be increasing the fitness of the robbed plants by promoting outcrossing. The robbers could then be considered as mutualists. Guitian et al. (1994) observed that nectar robbing by carpenter bees has a positive effect on seed set in Pterocoptis grandiflora. Zimmerman \& Cook (1985) and Castro et al. (2008, 2009) stated that nectar robbing besides influencing host female fitness, could potentially enhance male fitness and increase the offspring outcrossing rate by forcing legitimate pollinators to fly farther in search of nectar, thus expanding the pollen dispersal distance and neighbourhood size, and reducing geitonogamy. Nectar robbing by both Xylocopa and Anthophora could potentially enhance male fitness by driving the legitimate pollinator, M. gyrans to fly farther and farther 
in search of nectar. Such a foraging behavior by this pollinator and expands the pollen dispersal distance and promotes the out-crossing rate in $\mathrm{C}$. inerme.

Primack et al. (1981) reported that $C$. inerme is strongly protandrous but did not explain how it works with reference to the movements of stamens and stigma within the flower. They have also not mentioned whether there are different forms of flowers based on the position of stamens and style during the life of the flower. In this study, three forms of flowers have been distinguished with reference to the position of floral sex organs. The first form is characterized by elongated stamens and style which occur in close proximity to each other just after anthesis; this facilitates contact between the stamens and stigma. The second form is characterized by the scattered position of stamens and style. In the third form, the stamens are fully extended while the style is curved away from them, either to the left or to the right; subsequently the stamens curl inward and the style elongates. Interestingly, the three flower forms can be found within a cyme also. Such flower forms have been reported in C. molle (McMullen 2011). These forms of flowers appear to have evolved to prevent autonomous and facilitated selfing but certainly not geitonogamy. The strong protandry in $C$. inerme does not facilitate individual flowers from selfpollinating but it facilitates different flowers on the same plant to pollinate each other through geitonogamy. This is further substantiated by fruit set in geitonogamous pollinations. Although geitonogamy is self-fertilization, in that the pollen fertilizing the ovules originates from the same parent plant, different parts of branches of the plant may diverge genetically through somatic mutation (Roubik 1995). Such a genetic divergence was experimentally proved in Byrsonima crassifolia in which one of five trees used in experiments was initially found to be self-incompatible produced fruits through self-pollination when the flowering period was nearly over and in Pscidia carthagenensis in which one-day old artificially self-pollinated flowers did not set fruit but 2-day old flowers set some fruits (Baker et al. 1983). In $C$. inerme, the protandry is functional partially since fruit set occurs through geitonogamy. The protandry function in this species is important as an out-breeding mechanism and it is also reflected in the percentage of fruit set recorded through xenogamy. The high fruit set recorded in open-pollinations despite mechanisms which prevent self-pollination in individual flowers, strongly suggests that $C$. inerme is self-compatible. Geitonogamy would allow fruit set in isolated colonizing plants. Initial colonization occurs usually by a single seed floating in tidal water. As a result, certain floral mechanisms which promote out-crossing with its associated genetic advantages can be expected in established populations (Primack et al. 1981). In C. inerme, the protandry together with different positions of stamens and style in different sets of flowers would allow fruit set in isolated or congregated individuals while totally preventing selfing within individual flowers. Such a dual breeding system is advantageous for $C$. inerme to colonize new areas in mangrove and coastal areas and also the nearby terrestrial habitats. The prolific growth of $C$. inerme with its extensive root system in these areas is important to control land and beach erosion, and stabilize the forest floor.

Wheeler et al. (1992) noted that fruit or seed dispersal in Clerodendrum genus happens through birds. Keng (1990) reported that birds are probably involved in dispersal of fruit or seed in C. laevifolium. Lorence and Flynn (1997) stated that C. macrostegium is spread by fruit eating birds. In $C$. inerme, the fruit is a capsule and breaks into different lobes depending on the number of nutlets produced inside. Each lobe contains a nutlet. Birds such as Acridotheres tristis, Corvus splendens, C. macrorhynchos and Turdoides caudatus disperse nutlets or seeds in the study area, occur during the early winter season. Seed germination occurs as soon as the monsoon sets in during June.

A few workers have reported that Clerodendrum species serve as larval hosts for lycaenid butterflies. C. laevifolium is a larval host for Zelthus amasa maximinianus (Keng, 1990), C. glabrum for Hypolycaena philippus philippus (Ivor, 1994) and C. indicum for Spindasis vulcanus (Kunte, 2007). In the present study, field observations indicated that $C$. inerme is another larval host for S. vulcanus. Therefore, Clerodendrum genus is probably the best larval host plant for lycaenid butterflies. Further studies may provide more information on other butterflies that use this plant species as a larval host.

\section{REFERENCES}

Baker, H.G., K.S. Bawa, G.W. Frankie \& P.A. Opler (1983). Reproductive biology of plants in tropical forests, pp. 183-215. In: Golley, F.B. (ed.). Ecosystems of the World 14 A. Tropical rain forest ecosystems: Structure and Function. Elsevier Scientific Publishing Company, New York.

Barrows, E.M. (1976). Nectar robbing and pollination in Lantana camara (Verbenaceae). Biotropica 8: 132-135.

Barrows, E.M. (1980). Robbing of exotic plants by introduced carpenter and honey bees in Hawaii, with comparative notes. Biotropica 12: 23-29.

Castro, S., P. Silveira \& L. Navarro (2008). Consequences of nectar 
robbing for the fitness of a threatened plant species. Plant Ecology 199: 201-208; http://dx.doi.org/10.1007/s11258-008-9424-z

Castro, S., P. Silveira \& L. Navarro (2009). Floral traits variation, legitimate pollination, and nectar robbing in Polygala vayredae (Polygalaceae). Ecological Research 24: 47-55; http://dx.doi. org/10.1007/s11284-008-0481-5

Cruden, R.W., H.M. Hermann \& S. Peterson (1983). Patterns of nectar production and plant-pollinator coevolution, pp. 80-125. In: Bentley, B. \& T. Elias (eds.). The Biology of Nectaries. Columbia University Press, New York.

Fenster, C.B. (1991). Gene flow in Chamaecrista fasciculata (Leguminosae). Evolution 45: 398-422.

Guitian, J., J.J. Sanchez \& P. Guitian (1994). Pollination ecology of Petrocoptis grandiflora Rothm. (Caryophyllaceae); a species endemic to the north-west part of the Iberian peninsula. Botanical Journal of Linnean Society 115: 19-27; http://dx.doi. org/10.1111/j.1095-8339.1994.tb01764.x

Inouye, D.W. (1983). The ecology of nectar robbing, pp. 153-173. In: Bentley, B. \& T. Elias (eds.). The Biology of Nectaries. Columbia University Press, New York.

Ivor, M. (1994). Field Guide. Butterflies of Southern Africa. Struik Publishers, Cape Town, 210pp.

Keng, H. (1990). The Concise Flora of Singapore: Gymnosperms and Dicotyledons. Singapore University Press, Singapore, 222pp.

Kunte, K. (2007). India - A Lifescape. Butterflies of Peninsular India. Universities Press, 254pp.

Lacerda, L.D., J.E. Conde \& B. Kjerfve (2002). American Mangroves. pp. 1-62. In: Lacerda, L.D. (ed.). Mangrove Ecosystems: Function and Management. Springer, Berlin.

Lorence, D.H. \& T. Flynn (1997). New naturalized plant records for Kauai. Bishop Museum Occasional Papers 49: 9-13.

Mabberley, D.J. (2008). Mabberley's Plant-Book. Cambridge University Press, U.K., 1040pp.

McMullen, C.K. (2011). Nocturnal and diurnal pollination of Clerodendrum molle (Verbenaceae) in the Galapagos Islands. Plant Systematics \& Evolution 292: 15-23; http://dx.doi.org/10.1007/ s00606-010-0395-x

Meerabai, G. (2014). A study on co-evolutionary relationship of four plants with their butterfly pollinators on the basis of their nectar physiology. Environment and Natural Resources Research 4: 65-69; http://dx.doi.org/10.5539/enrr.v4n2p65

Parani, M., M. Lakshmi \& P. Senthilkumar (1998). Molecular phylogeny of mangroves. V. Analysis of genome relationships in mangrove species using RAPD and RFLP markers. Theoretical and Applied Genetics 97: 617-625

Pleasants, J.M. (1983). Nectar production in Ipomopsis aggregata (Polemoniaceae). American Journal of Botany 70: 1468-1475.

Primack, R.B., N.C. Duke \& P.B. Tomlinson (1981). Floral morphology in relation to pollination ecology in five Queensland coastal plants. Austrobaileya 4: 346-355.
Raju, A.J.S. \& B. Rajesh (2014). Pollination ecology of Chengam Scyphiphora hydrophyllacea C.F. Gaertn. (Magnoliopsida: Rubiales: Rubiaceae). a non-viviparous evergreen tree species. Journal of Threatened Taxa 6(14): 6668-6676; http://dx.doi.org/10.11609/ JoTT.03998.6668-76

Reddy, T.B. \& C.S. Reddi (1995). Butterfly pollination of Clerodendrum infortunatum (Verbenaceae). Journal of the Bombay Natural History Society 92: 166-173.

Rohitash \& R.K. Jain (2010). Reproductive Biology of Clerodendrum splendens (Verbenaceae). Advances in Bioresearch 1: 84-86.

Roubik, D.W. (1995). Pollination of Cultivated Plants in the Tropics. FAO Agricultural Services Bulletin 118.

Saenger, P. (2002). Mangrove Ecology, Silviculture and Conservation. Kluwer Academic Publishers, Dordrecht, the Netherlands.

Sakamoto, R.L., M. Ito \& N. Kawakubo (2012). Contribution of pollinators to seed production as revealed by differential pollinator exclusion in Clerodendrum trichotomum (Lamiaceae). PLOS ONE 7: 1-7; http://dx.doi.org/10.1371/journal.pone.0033803

Satynarayana, B., A.V. Raman \& F. Dehairs (2002). Mangrove floristic and zonation patterns of Coringa, Kakinada Bay, East Coast of India. Wetlands Ecology and Management 10: 25-37.

Shamim, A.L., Md.O. Rahmani, M.Z. Uddin, M.A. Hassan \& M. Begum (2010). Reproductive biology of three medicinal plants. Bangladesh Journal of Plant Taxonomy 17: 69-78; http://dx.doi.org/10.3329/ bjpt.v17i1.5391

Tomlinson, P.B. (1986). The Botany of Mangroves. Cambridge University Press, 419pp.

van der Pijl, L. (1954). Xylocopa and flowers in the Tropics. I-III. Proceedings of Kokinklijke Nederlandse Akademie van Wetenschappen Series C 57: 413-423; 514-562.

Wang, L., M. Mu, X. Li, P. Lin \& W. Wang (2011). Differentiation between true mangroves and mangrove associates based on leaf traits and salt contents. Journal of Plant Ecology 4: 292-301; http:// dx.doi.org/10.1093/jpe/rtq008

Wheeler, J.R., B.L. Rye, B.L. Koch \& A.J.G. Wilson (1992). Western Australian Herbarium. Flora of the Kimberley Region. Western Australian Herbarium, Como, W.A, 1392pp.

Yao-Wu, Y., D.J. Mabberley, A.S. Dorothy \& R.G. Olmstead (2010). Further disintegration and redefinition of Clerodendrum (Lamiaceae): Implications for the understanding of the evolution of an intriguing breeding strategy. Taxon 59: 125-133.

Zhang, Y.W., Q. Yu, J.M. Zhao \& Y.H. Guo (2009). Differential effects of nectar robbing by the same bumble-bee species on three sympatric Corydalis species with varied mating systems. Annals of Botany 104: 33-39; http://dx.doi.org/10.1093/aob/mcp104

Zimmerman, M. \& S. Cook (1985). Pollinator foraging, experimental nectar-robbing and plant fitness in Impatiens capensis. American Midland Naturalist 113: 84-91. 